\title{
UPAYA PENINGKATAN KESEHATAN FISIK DAN PSIKIS SISWA MTS PONDOK PESANTREN AL-QUR'AN HARSALLAKUM KOTA BENGKULU
}

\author{
${ }^{1}$ Fatsiwi Nunik Andari, ${ }^{2}$ Susilawati, ${ }^{3}$ Bintang Agustina Pratiwi \\ ${ }^{1,2}$ Program Studi Ilmu Keperawatan \\ ${ }^{3}$ Program Studi Kesehatan Masyarakat \\ Fakultas Ilmu Kesehatan Universitas Muhammadiyah Bengkulu \\ Coresponden author : fatsiwiandari@umb.ac.id
}

Informasi Artikel

Terima : 31/03/2021

Revisi : 22/05/2021

Disetujui : $12 / 08 / 2021$

\section{Kata Kunci:}

cantengan, covid-19, sehat fisik dan psikis, skabies

\begin{abstract}
ABSTRAK
Pondok pesantren pada umumnya berbentuk asrama atau kamar-kamar kecil dengan desain bangunan yang sederhana. Dalam kesehariannya para santri/siswa menempati satu kamar yang biasanya dihuni oleh lebih dari 3 orang. Kondisi ini dapat menyebabkan munculnya berbagai macam penyakit menular, khususnya di masa pandemi Covid-19 saat ini. Kondisi ini tentu saja memberikan ancaman kesehatan baik secara fisik maupun secara psikis bagi para siswa, bahkan ancaman kesehatan ini dapat berdampak pula pada ancaman kematian. Ancaman kesehatan fisik yang terjadi di Pondok Pesantren Harsallakum Kota Bengkulu diantaranya penyakit skabies, cantengan (paronikia) dan Corona Virus Desease-19 (covid19). Untuk mencegah dampak yang lebih jauh dari tidak sehatnya fisik dan psikis para siswa, perlu dilakukan upaya edukasi kesehatan dalam bentuk penyuluhan kesehatan. Kegiatan ini bertujuan untuk meningkatkan pengetahuan dan wawasan siswa sehingga dapat menjaga kesehatan fisik dan kesehatan psikis guna mencegah penularan penyakit. Melalui kegiatan pengabdian ini, pengetahuan siswa tentang penyakit skabies, cantengan, covid-19 dan perkembangan psikologi remaja meningkat. Pengetahuan yang telah dimiliki diharapkan dapat diterapkan dalam kesehariannya dan menjadikan siswa pondok pesantren sehat baik secara fisik maupun psikis.
\end{abstract}

\section{PENDAHULUAN}

Pondok pesantren didefinisikan sebagai sebuah lembaga keagamaan yang memberikan pendidikan dan pengajaran serta mengembangkan dan menyebarkan ilmu agama Islam. Pada umumnya pondok pesantren berbentuk asrama atau kamar-kamar kecil dengan 
desain bangunan apa adanya yang menunjukkan kesederhanaannya.

Pondok pesantren dihuni oleh para siswa yang sering disebut juga dengan dengan istilah santri yaitu santriwan untuk santri laki-laki dan santriwati untuk santri perempuan (Yasmadi, 2002).

Dalam kesehariannya para santri menempati satu kamar yang biasanya dihuni oleh lebih dari 3 orang. Kondisi ini tentu dapat menyebabkan munculnya berbagai macam penyakit yang dapat menularkan dari satu santri ke santri lainnya, khususnya di masa pandemi Covid-19 saat ini. Di masa pandemi Covid-19 yang mengharuskan setiap individu menerapkan protokol kesehatan seperti menjaga jarak satu sama lain, menjaga kebersihan diri, mempertahankan sirkulasi udara yang baik sulit untuk dapat dilakukan oleh para santri yang tinggal dalam satu kamar berukuran kecil (Kemenkes RI, 2020).

Kondisi pandemi Covid-19 ini tentu saja memberikan ancaman kesehatan baik secara fisik maupun secara psikis bagi para santri, bahkan ancaman kesehatan ini dapat berdampak pula pada ancaman kematian. Ancaman kesehatan fisik yang sering terjadi di pondok pesantren diantaranya adalah penyakit skabies. Skabies merupakan jenis penyakit kulit yang disebabkan oleh infestasi dan sensitisasi terhadap Sarcoptes scabiei var hominis, dan produknya, ditandai dengan gatal pada malam hari khususnya di lipatan-lipatan kulit yang tipis, hangat, dan lembab (Ronny, 2007).

Angka kejadian skabies di Indonesia berdasarkan data Riskesdas tahun 2018 sebanyak 6,9\%. Penyakit ini berada pada peringkat ketiga dari dua belas penyakit kulit tersering yang diderita oleh masyarakat. Bengkulu termasuk salah satu provinsi yang mempunyai prevalensi penyakit kulit di atas prevalensi nasional. Berdasarkan hasil wawancara dengan petugas kesehatan Pondok Pesantren Al-Qur'an Harsallakum, sebagian besar siswa mengalami penyakit skabies dengan gejala gatal-gatal pada kulit sekitar tubuh dan di sela-sela jari tangan dan kaki.

Selain skabies, para siswa di Pondok Pesantren Al-Qur'an Harsallakum juga banyak yang mengalami masalah kesehatan berupa cantengan yang dalam bahasa medisnya disebut dengan istilah paronikia. Cantengan (paronikia) merupakan 
kejadian luka infeksi pada jaringan sekitar kuku yang disebabkan oleh perawatan kuku yang tidak tepat misalnya pemotongan kuku yang salah seperti memotong kuku terlalu pendek atau miring, kebiasaan mencungkil kuku yang kotor. Cantengan sering dapat bersifat akut ataupun kronis. Kondisi ini ditandai dengan keluhan nyeri, bengkak, dan kemerahan pada area di sekitar kuku serta mengeluarkan cairan nanah atau pus (d'Almeida et al., 2016).

Cantengan yang dialami oleh siswa Pondok Pesantren Al-Qur'an Harsallakum lebih sering terjadi pada kuku ibu jari kaki. Kuku kaki merupakan bagian tubuh yang paling dekat dengan tanah namun jauh dari jangkauan anggota tubuh lainnya sehingga sering disebut sebagai sumber kuman. Oleh karena itu bila terjadi luka maka akan mudah mengalami infeksi. Infeksi cantengan merusak barier antara lapisan-lapisan kuku dan jaringan di sekitarnya sehingga menyebabkan organisme seperti jamur dan bakteri dapat dengan mudah masuk ke area tersebut dan menyebabkan infeksi sekunder. Bakteri Staphylococcus aureus dan jamur Candida albican merupakan organisme yang sering ditemukan pada paronikia. Kondisi ini membutuhkan penanganan yang adekuat agar tidak menimbulkan dampak yang lebih parah. Menurut D'Almeida et al., (2016) penatalaksanaan cantengan kronik yang tidak adekuat dapat menimulkan komplikasi berupa osteomielitis.

Tingginya resiko penularan penyakit skabies, cantengan dan resiko covid-19 di lingkungan pondok pesantren merupakan bentuk ancaman terhadap kesehatan fisik para santri. Kesehatan fisik dapat memberikan pengaruh pada kesehatan psikis atau kondisi psikologis seseorang. Berbagai penelitian telah mengungkapkan adanya hubungan antara kesehatan fisik dan mental (psikis) individu. Begitu juga sebaliknya, individu dengan gangguan mental juga menunjukkan adanya gangguan pada fungsi fisiknya. Hal ini dikarenakan sehat dan sakit merupakan kondisi biopsikososial yang menyatu dalam kehidupan manusia. Kesehatan mental merupakan hal penting yang harus diperhatikan selayaknya kesehatan fisik. Kondisi kestabilan kesehatan mental dan fisik saling mempengaruhi. Kondisi mental yang sehat tidak dapat terlepas dari kondisi kesehatan fisik yang baik (Holzberg \& Baran, 2012) 
Resiko tinggi terhadap penularan penyakit skabies, cantengan dan covid19 di masa pandemi ini memberikan kekhawatiran bagi para siswa MTS. Kekhawatiran yang berlebihan dapat menimbulkan kepanikan. Kondisi ini dapat menyebabkan psikis siswa menjadi tidak sehat ataupun stress. Stress yang tidak diatasi dapat mempengaruhi sistem tubuh, khususnya berdampak pada kesehatan dimana dapat terjadinya penurunan pada sistem imunitas atau daya tahan tubuh. Untuk mencegah dampak yang lebih jauh dari tidak sehatnya fisik dan psikis para santri di Pondok Pesantren Al-Qur'an Harsallakum Kota Bengkulu, maka perlu dilakukan sebuah upaya pemberian pendidikan kesehatan.

Pendidikan kesehatan merupakan suatu proses yang direncanakan untuk mempengaruhi atau mengajak orang lain, baik individu, kelompok atau masyarakat agar melaksanakan perilaku hidup yang sehat (N. Nursalam \& Efendi, 2008). Hal ini sejalan dengan hasil penelitian Dewi (2013) bahwa pemberian pendidikan kesehatan berpengaruh terhadap peningkatan pengetahuan penderita skabies tentang penyakit skabies di Desa Geneng Sari Kecamatan Kemusu Kabupaten
Boyolali. Meningkatnya pengetahuan siswa tentang penyakit skabies, cara perawatan kaki untuk mencegah cantengan dan covid-19 juga dibuktikan pada hasil penelitian (Fitriyani, 2017), (Istiqomah, 2017) serta (Wulandari., Anisa, Fitriania, dan Purnamasari 2020). Pendidikan kesehatan yang diberikan dalam kegiatan pengabdian pada masyarakat ini meliputi materi tentang penyakit skabies, cantengan dan Covid-19. Upaya ini bertujuan untuk meningkatkan pengetahuan siswa agar lebih memahami penyakit skabies, cantengan dan Covid-19. Sementara itu upaya yang dilakukan untuk meningkatkan kesehatan psikis guna mengurangi ketegangan dan stress para siswa di masa pandemi ini adalah dengan memberikan penyuluhan kesehatan tentang perkembangan psikologi pada remaja. Hal ini mengingat bahwa siswa MTS berada pada tahapan usia remaja yang saat ini berhadapan dengan situasi pandemi yang tentunya memberikan pengaruh pada perubahan aktifitas sehari-harinya.

Oleh karena itu pemberian pendidikan kesehatan dalam pengabdian pada masyarakt ini sangat penting untuk dilakukan. Karena melalui kegiatan ini pengetahuan siswa dapat meningkat 
sehingga diharapkan siswa dapat menerapkan pola hidup sehat guna memutus mata rantai penularan penyakit skabies, cantengan dan penyebaran Covid-19 di lingkungan Pondok Pesantren Al-Qur'an Harsallakum Kota Bengkulu.

\section{METODE KEGIATAN}

Kegiatan ini dilaksanakan di Pondok Pesantren Al-Qur'an Harsallakum Kota Bengkulu pada bulan Februari-Maret 2021 yang diikuti oleh perwakilan siswa MTS kelas VII, VIII, dan IX. Pelaksanaan kegiatan pengabdian pada masyarakat ini diawali dengan melakukan analisis situasi atau survey lokasi untuk melihat sejauhmana masalah kesehatan yang terjadi di Pondok Pesantren Harsallakum Kota Bengkulu. Pada tahap ini juga dilakukan penandatanganan Memorandum of Understanding (MoU) kerjasama antara tim pengabdian pada masyarakat $(\mathrm{PkM})$ dengan pihak sekolah serta penetapan materi yang akan diberikan dalam penyuluhan.

Tahap selanjutnya adalah melakukan pemeriksaan kondisi kulit siswa untuk mendeteksi tanda-tanda penyakit skabies yang diderita, lokasi yang terkena skabies dan mengobservasi kondisi luka akibat garukan yang dilakukan karena rasa gatal yang dirasakan siswa. Selain itu dilakukan juga pemeriksaan jari dan kuku kaki siswa untuk melihat kondisi cantengan yang terjadi.

Kegiatan dilanjutkan ke tahap pemberian materi kesehatan tentang skabies, cantengan, covid-19 dan perkembangan psikologi remaja yang dibagi dalam beberapa kali pertemuan dengan tujuan untuk memberikan pemahaman dan kesadaran kepada siswa. Pemberian materi kesehatan ini dilakukan dengan cara penyuluhan.

\section{HASIL DAN PEMBAHASAN}

a. Kegiatan Awal

Hasil yang diperoleh dari kegiatan analisis situasi atau survey lokasi yang dilakukan di awal kegiatan pengabdian pada masyarakat ini adalah didapatkannya informasi mengenai jumlah siswa yang mengalami penyakit skabies dan cantengan. Berdasarkan hasil wawancara dengan petugas kesehatan sekolah, sebagian besar siswa Pondok Pesantren Al-Qur'an Harsallakum Kota Bengkulu. mengalami skabies dan cantengan. Hal ini juga diperkuat oleh 
penjelasan Kepala Sekolah saat dilakukan penandatanganan $\mathrm{MoU}$ kerjasama. Pada kegiatan awal ini juga ditetapkan materi-materi yang akan diberikan pada penyuluhan kesehatan.

Berikut adalah dokumentasi kegiatan penandatanganan MoU kerjasama antara tim PkM FIKES UM Bengkulu dengan Pondok Pesantren Al-Qur'an Harsallakum Kota Bengkulu :

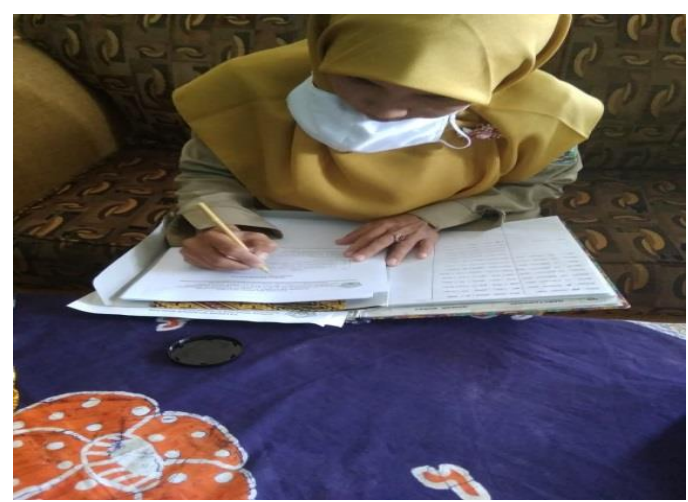

Pondok pesantren merupakan salah satu tempat yang memiliki faktor risiko tinggi untuk terjadinya penyakit skabies. Hal ini dikarenakan pondok pesantren memiliki hunian yang padat sehingga frekuensi kontak antara satu siswa dengan siswa lainnya cukup intens baik secara langsung maupun tidak langsung. Tempat dengan hunian yang padat serta kebersihan lingkungan yang tidak dijaga akan mempermudah transmisi dan penularan tungau skabies (Soemirat, 2011). World Health Organization (WHO) juga menyatakan bahwa penyakit skabies erat kaitannya dengan kebersihan perseorangan dan lingkungan atau terdapat banyak orang yang tinggal bersama-sama disatu tempat yang relatif sempit.

b. Kegiatan Pemeriksaan Kondisi Kulit Siswa

Hasil yang diperoleh dari pemeriksaan kondisi kulit siswa adalah didapatkannya benjolan atau lepuhan kecil berwarna merah pada area tubuh tertentu seperti pada tangan, sela-sela jari tangan, pergelangan tangan, daerah siku, dan daerah sekitar lipatan lutut serta di sela-sela jari kaki. Siswa juga mengatakan bahwa area tubuh tersebut terasa sangat gatal, terutama di malam hari sehingga terpaksa digaruk yang mengakibatkan terjadinya luka.

Berikut adalah dokumentasi kegiatan pemeriksaan kondisi kulit siswa yang mengalami skabies dan cantengan : 


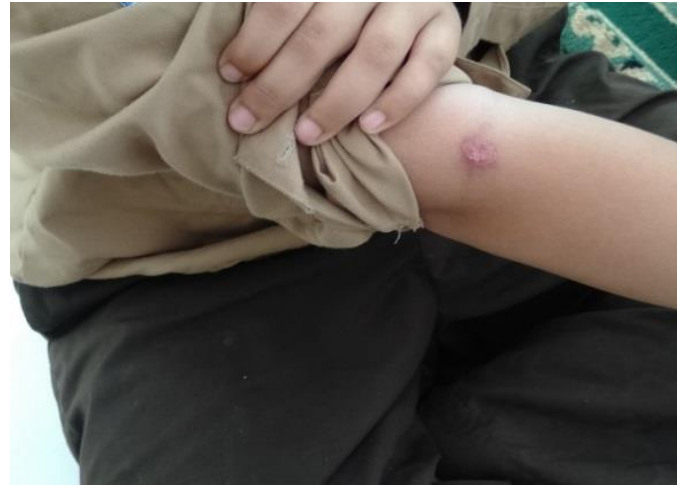

Dokumentasi pemeriksaan kulit siswa yang mengalami skabies

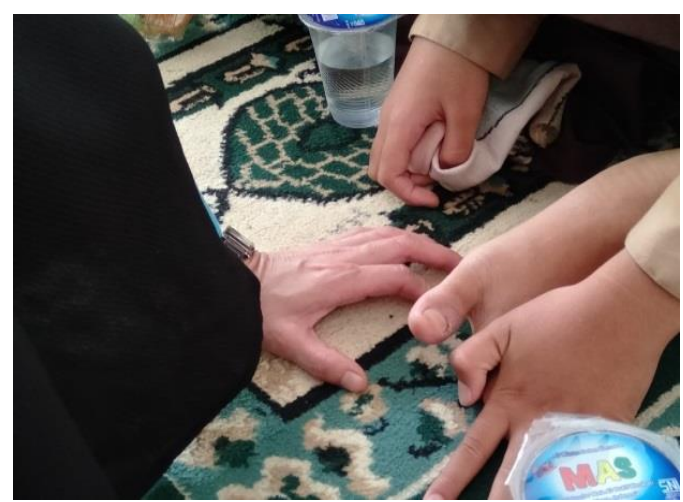

Dokumentasi pemeriksaan kulit siswa yang mengalami cantengan

Siregar (2006) menyatakan bahwa penyakit skabies yang disebabkan oleh tungau menimbulkan ruam pruritus yang menyebar hampir di seluruh tubuh disertai dengan rasa gatal yang berat dan memburuk di malam hari. Rasa sangat gatal akibat skabies dapat mengganggu kualitas tidur. Gatal pada malam hari berhubungan dengan mediator gatal atau disebabkan oleh perubahan fisiologis kulit seperti suhu kulit dan juga fungsi pertahanan kulit (Djuanda, 2017).

Hasil yang diperoleh dari pemeriksaan jari dan kuku kaki siswa adalah terdapatnya luka infeksi pada jaringan sekitar kuku jari kaki. Luka infeksi ini merupakan manifestasi dari penyakit cantengan, yang dalam istilah medis disebut dengan paronikia. Cantengan merupakan kejadian luka infeksi pada jaringan sekitar kuku yang disebabkan oleh perawatan kuku yang tidak tepat misalnya pemotongan kuku yang salah seperti memotong kuku terlalu pendek atau miring, kebiasaan mencungkil kuku yang kotor. Cantengan sering dapat bersifat akut ataupun kronis. Kondisi ini ditandai dengan keluhan nyeri, bengkak, dan kemerahan pada area di sekitar kuku serta mengeluarkan cairan nanah atau pus (d'Almeida et al., 2016).

Petugas kesehatan sekolah juga memberikan penjelasan bahwa banyak siswa yang mengalami kejadian cantengan pada ibu jari kaki dan harus mendapatkan perawatan luka di Unit Kesehatan Sekolah (UKS). Penyakit cantengan biasanya berhubungan dengan adanya trauma 
pada kutikula dan aktivitas yang melibatkan kontak dengan air seperti mencuci baju atau piring. Hal ini dikarenakan kuku kaki merupakan bagian tubuh yang paling dekat dengan tanah namun jauh dari jangkauan anggota tubuh lainnya sehingga sering disebut sebagai sumber kuman. Oleh karena itu bila terjadi luka maka akan mudah mengalami infeksi.

Menurut (D'Almeida et al., 2016) infeksi cantengan akan merusak barier antara lapisan-lapisan kuku dan jaringan di sekitarnya sehingga menyebabkan organisme seperti bakteri dan jamur dapat dengan mudah masuk ke area tersebut dan menyebabkan infeksi sekunder. Bakteri Staphylococcus aureus dan jamur Candida albican merupakan organisme yang sering ditemukan pada paronikia.

c. Kegiatan Penyuluhan Kesehatan

Kegiatan penyuluhan kesehatan dilaksanakan di dalam Masjid Pondok Pesantren Al-Qur'an Harsallakum dengan pertimbangan ruangan yang luas dan terbuka. Sebelum kegiatan penyuluhan kesehatan dimulai, pihak sekolah dalam hal ini Kepala Sekolah memberikan sambutan sekaligus membuka acara penyuluhan kesehatan oleh tim PkM FIKES UM Bengkulu. Kegiatan pembukaan diakhiri dengan pembacaan doa oleh perwakilan guru pondok pesantren.

Berikut adalah dokumentasi kegiatan pembukaan penyuluhan kesehatan :

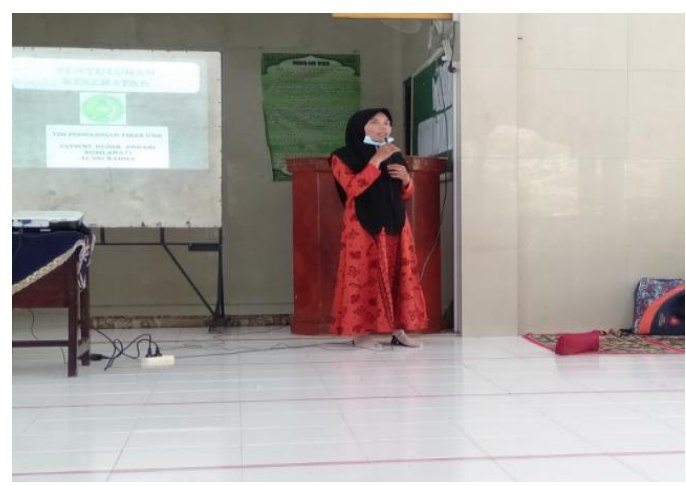

Dokumentasi sambutan Kepala

Sekolah dalam acara pembukaan

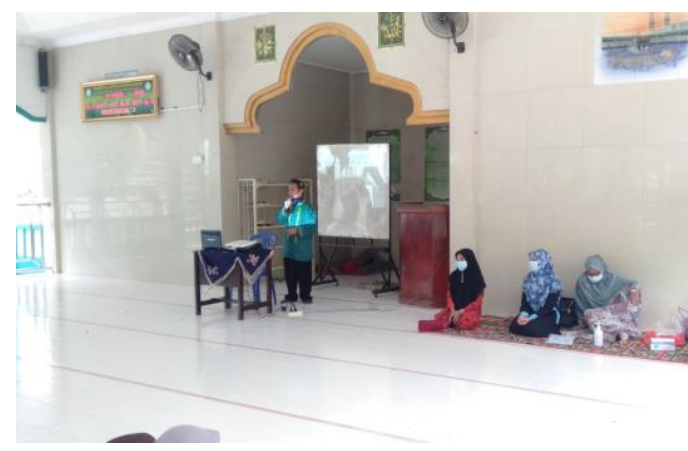

Dokumentasi pembacaan doa dalam acara pembukaan

Hasil yang diperoleh dari pemberian penyuluhan kesehatan 
tentang penyakit skabies dan cantengan dengan metode ceramah didapatkan hasil adanya peningkatan pengetahuan siswa peserta penyuluhan terkait materi skabies dan cantengan yang telah diberikan dibandingkan dengan sebelumnya. Hal ini terlihat dari kemampuan peserta penyuluhan dalam menjawab pertanyaan-pertanyaan yang diberikan oleh pemateri.

Berikut adalah dokumentasi kegiatan penyuluhan kesehatan yang dilakukan :

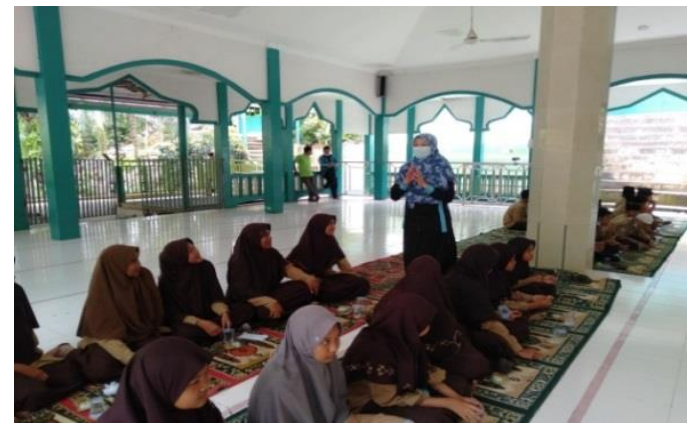

Dokumentasi kegiatan penyuluhan kesehatan

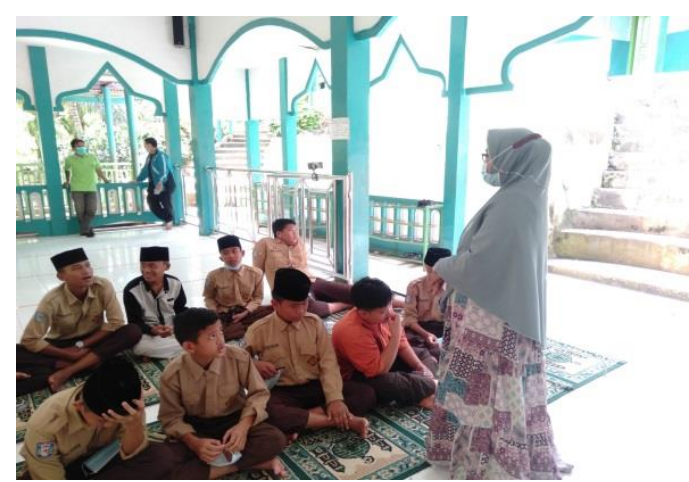

Dokumentasi kegiatan penyuluhan

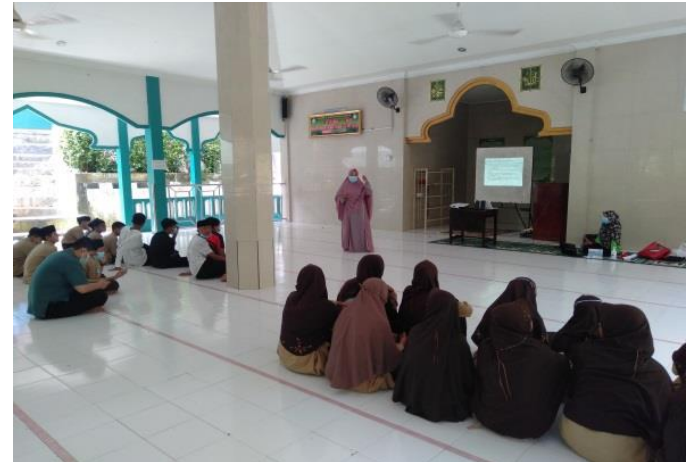

Dokumentasi kegiatan penyuluhan kesehatan

Setelah materi penyuluhan diberikan oleh tim PkM, dilanjutkan dengan sesi diskusi atau sesi tanya jawab dengan peserta penyuluhan. Antusiasme yang tinggi untuk bertanya ditunjukkan oleh peserta penyuluhan. Peserta penyuluhan menanyakan kondisi yang mereka rasakan

Berikut dokumentasi kegiatan pada sesi tanya jawab :

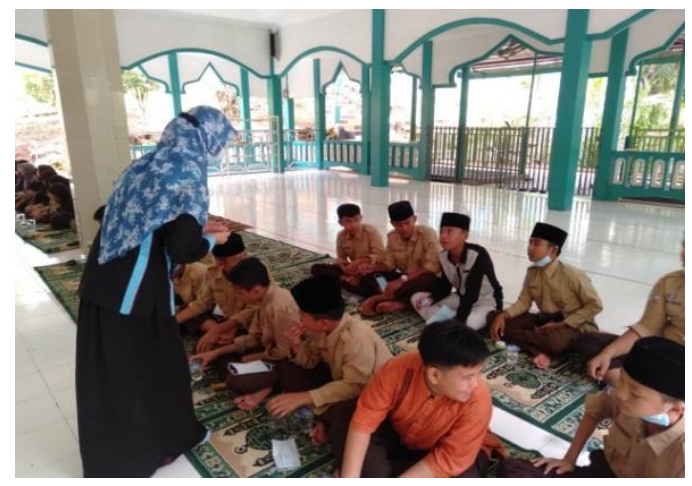

Dokumentasi sesi tanya jawab

kesehatan 


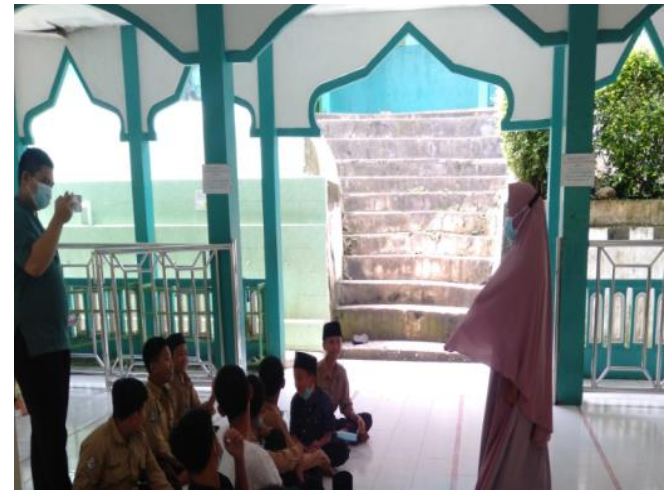

Dokumentasi sesi tanya jawab

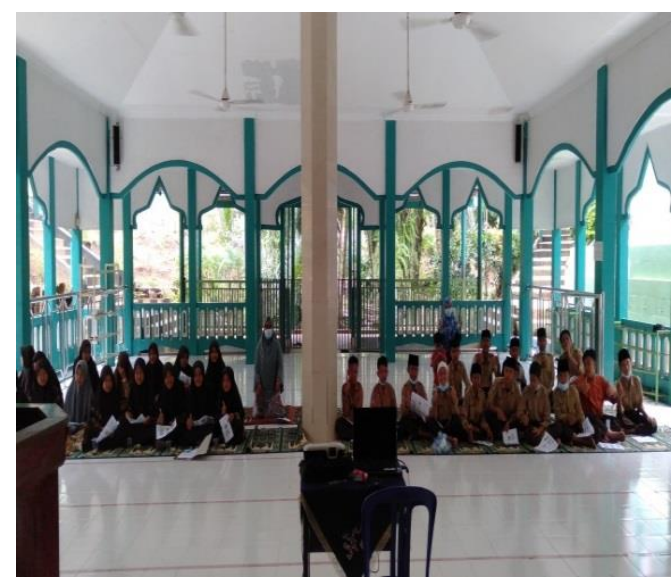

Dokumentasi peserta peyuluhan

Hasil penyuluhan kesehatan menunjukkan bahwa peserta penyuluhan dapat memahami dengan baik materi penyuluhan yang diberikan dan beberapa diantaranya mampu memberikan ringkasan materi yang telah diberikan tim pemateri. Antusiasme yang tinggi juga ditunjukkan oleh peserta penyuluhan saat sesi tanya jawab, dimana banyak diantara peserta penyuluhan memberikan pertanyaan seputar kondisi yang dialami yang

sesuai dengan topik materi penyuluhan.

Meningkatnya pengetahuan siswa peserta penyuluhan ini sejalan dengan hasil (Fitriyani, 2017) yang memberikan pendidikan kesehatan tentang skabies kepada santri Pesantren Asshiddiyah Jakarta. Hasil yang sama juga diungkapkan (Amri, 2019) bahwa tingkat pengetahuan santri di Pondok Pesantren ArRisalah Mlangi Nogotirto Gamping Sleman Yogyakarta meingkat setelah diberikan penyuluhan kesehatan tentang skabies. Pengetahuan merupakan hasil dari tahu, dan hal ini terjadi setelah individu melakukan penginderaan melalui indera penglihatan, pendengaran, penciuman, perasa, dan peraba terhadap suatu obyek tertentu. Pengetahuan sebagian besar diperoleh oleh seorang individu melalui indera mata dan telinga (Notoatmodjo, 2003).

\section{Meningkatnya pengetahuan} siswa setelah diberikan penyuluhan turut dipengaruhi oleh faktor internal dan eksternal. Faktor internal yang dimaksud adalah umur, pengalaman, pendidikan, dan faktor eksternalnya adalah informasi. Menurut 
(Nursalam, 2014) semakin cukup umur, tingkat kematangan seseorang akan lebih matang dalam berpikir dan bekerja. Umur siswa dalam penyuluhan ini dikategorikan sudah cukup untuk dapat menerima informasi kesehatan yang diberikan dengan baik.

Ditinjau dari faktor pengalaman, sebagian besar siswa telah memiliki pengalaman menderita penyakit skabies, sehingga pengalaman yang dimiliki siswa dapat dijadikan sebagai upaya untuk memperoleh pengetahuan tentang skabies. Dari segi pendidikan, siswa peserta penyuluhan berada pada tahap pendidikan menengah pertama yang merupakan lanjutan dari sekolah tingkat dasar sehingga pada tahap pendidikan ini, siswa tidak memiliki hambatan dalam menerima nilai-nilai yang baru diperkenalkan.

Faktor eksternal berupa informasi merupakan hal yang sangat penting untuk membantu mengurangi kecemasan. Individu yang mendapatkan informasi akan mempertinggi tingkat pengetahuannya terhadap suatu hal sehingga kecemasan yang dirasakan akan berkurang (Nursalam, 2011).
Kecemasan atau ansietas adalah perasaan takut akan terjadinya sesuatu yang disebabkan oleh antisipasi bahaya. Kecemasan merupakan sinyal yang membantu individu untuk dapat bersiap mengambil tindakan dalam menghadapi ancaman. Adanya tuntutan, persaingan dan bencana yang terjadi dalam kehidupan memberi dampak bagi kesehatan fisik dan psikologis. Kecemasan merupakan salah satu dampak psikologis yang muncul (Keliat, 2011).

Informasi kesehatan berupa penyuluhan tentang penyakit skabies, cantengan, covid-19 dan perkembangan psikologi remaja menambah tingkat pengetahuan siswa sehingga mampu mengurangi kecemasan yang dirasakan. Siswa menjadi lebih tahu tentang kondisi penyakit yang dialaminya, langkahlangkah yang harus dilakukan agar terhindar dari penyakit ini dan bagaimana upaya untuk dapat memutus mata rantai penyakit ini. Dengan semakin tingginya pengetahuan yang dimiliki siswa maka kecemasan yang dirasakan akibat kondisi ini dapat berkurang. 
Dengan demikian metode penyuluhan kesehatan dalam kegiatan pengabdian pada masyarakat ini merupakan solusi untuk meningkatkan kesehatan fisik dan psikis siswa di masa pandemi.

d. Kegiatan Akhir

Kegiatan akhir pengabdian masyarakat di Pondok Pesantren AlQur'an Harsallakum Kota Bengkulu dilaksanakan pada tanggal 29 Maret 2021. Dalam kegiatan ini disampaikan terkait hasil seluruh kegiatan yang sudah dilakukan tim $\mathrm{PkM}$, dimulai dari kegiatan analisis situasi lokasi dan sasaran PkM, kegiatan penilaian kondisi kulit siswa khususnya yang mengalami scabies dan atau cantengan, pelaksanaan penyuluhan kesehatan tentang scabies, cntengan, covid-19 dan perkembangan psikologi remaja.

Dalam kegiatan ini tim PkM mohon izin berpamitan dan mengucapkan terima kasih kepada pihak sekolah yang telah memberikan kesempatan bekerjasama dengan tim PkM Program Studi Ners FIKES UM Bengkulu untuk dapat mentransfer ilmu pengetahuan yang didapat pada masyarakat secara langsung. Selain itu pada kesempatan ini tim PkM juga menyampaikan permohonan maaf kepada pihak sekolah apabila terdapat kesalahan dalam kata-kata dan sikap yang kurang berkenan selama melakukan kegiatan $\mathrm{PkM}$ di pondok pesantren Al-Qur'an Harsallakum Kota Bengkulu ini. Tim PkM berharap kerjasama ini dapat terus berlanjut di masa yang akan datang. Kegiatan diakhiri dengan penyerahan kenangkenangan dari Tim PkM kepada pihak sekolah.

Berikut dokumentasi penyerahan kenang-kenangan dari tim PkM :

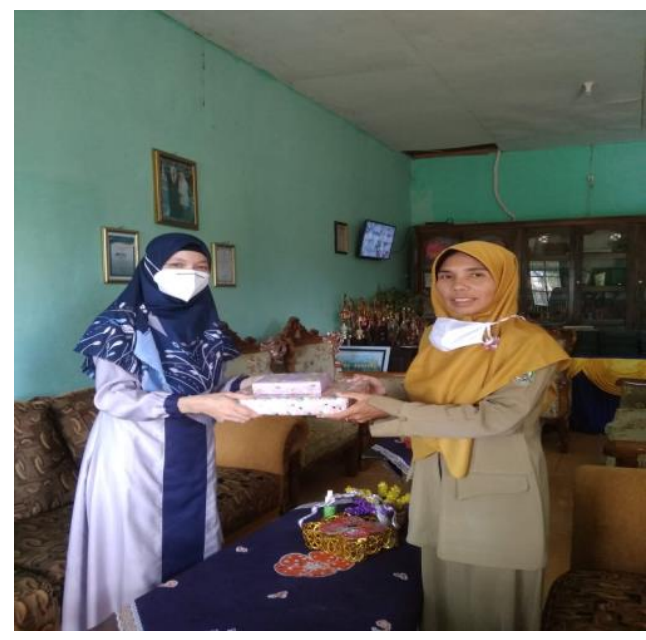

Penyerahan kenang-kenangan kepada pihak sekolah 
PENUTUP

\section{Kesimpulan}

Hasil dari pelaksanaan kegiatan pengabdian masyarakat ini adalah:

1. Kegiatan awal dimulai dengan melakukan analisis situasi untuk mengetahui gambaran lokasi dan sasaran kegiatan PkM, yang dalam hal ini adalah siswa MTS Pondok Pesantren Al-Qur'an Harsallakum. Kegiatan ini diikuti oleh 40 orang yang terdiri dari kepala sekolah, guru, perwakilan siswa MTS kelas VII, VIII, IX dan tim PkM. Pada kegiatan awal ini juga disampaikan rangkaian kegiatan yang akan dilakukan mulai dari pemeriksaan kondisi kulit siswa, memberikan penyuluhan kesehatan tentang skabies, cantengan, covid-19 dan perkembangan psikologi remaja.

2. Kegiatan pemeriksaan kondisi kulit siswa yang mengalami scabies dan cantengan. Kegiatan ini diikuti oleh perwakilan siswa MTS yang akan mengikuti penyuluhan kesehatan. Hasil dari kegiatan ini didapatkan bahwa terdapat benjolan atau lepuhan kecil berwarna merah pada area tubuh tertentu seperti pada tangan, sela-sela jari tangan, pergelangan tangan, daerah siku, dan daerah sekitar lipatan lutut serta di selasela jari kaki. Hasil yang diperoleh dari pemeriksaan jari dan kuku kaki siswa adalah terdapatnya cantengan yaitu luka infeksi pada jaringan sekitar kuku jari kaki.

3. Kegiatan pendidikan kesehatan tentang penyakit scabies dan cantengan diikuti oleh 32 siswa sementara untuk penyuluhan kesehatan tentang penyakit covid19 dan perkembangan psikologi remaja diikuti oleh 29 siswa. Terdapat peningkatan pengetahuan siswa MTS terhadap materi penyuluhan yang diberikan.

4. Kegiatan akhir PkM berupa penyampaian laporan hasil seluruh kegiatan yang sudah dilakukan oleh tim pengabdian pada masyarakat kepada pihak sekolah.

\section{Saran}

Kegiatan penyuluhan kesehatan di Pondok Pesantren Al-Qur'an Harsallakum Kota Bengkulu sebaiknya dilakukan secara rutin dan terus menerus dengan melibatkan 
pihak-pihak terkait seperti Dinas Kesehatan dan Puskesmas wilayah kerja setempat agar pengetahuan dan pemahaman siswa-siswa MTS tentang kesehatan meningkat sehingga harapannya dapat meningkatkan derajat kesehatan siswa untuk tumbuh dan berkembang dengan optimal sebagai generasi penerus bangsa.

\section{DAFTAR PUSTAKA}

Amri, M. H. (2019). Pengaruh Penyuluhan Personal Hygiene Terhadap Tingkat Pengetahuan Tentang Skabies Pada Santri Putra Di Pondok Pesantren Ar-Risalah Mlangi Nogotirto Gamping Sleman Yogyakarta. Universitas' Aisyiyah Yogyakarta.

d'Almeida, L. F. V., Papaiordanou, F., Machado, E. A., Loda, G., Baran, R., \& Nakamura, R. (2016). Chronic paronychia treatment: Square flap technique. Journal of the American Academy of Dermatology, 75(2), 398-403.

Dewi, V. Y., Abi Muhlisin, H. M., \& Ambarwati, S. P. (2013). Pengaruh Pendidikan Kesehatan Terhadap Pengetahuan Dan Sikap Pada Penderita Skabies Tentang Penyakit Skabies Di Desa Geneng Sari Kecamatan Kemusu Kabupaten Boyolali. Universitas Muhammadiyah Surakarta.

Djuanda, A., Hamzah, M., \& Aisah, S. (2017). Ilmu Penyakit Kulit \& Kelamin. Jakarta: Badan Penerbit Fakultas Kedokteran Universitas Indonesia.

Fitriyani, N. (2017). Efektivitas pendidikan kesehatan tentang skabies terhadap tingkat pengetahuan santri Pesantren Asshiddiqiyah Jakarta. UIN Syarif Hidayatullah Jakarta: Fakultas Kedokteran dan Ilmu Kesehatan, 2017.

Holzberg, M., \& Baran, R. (2012). The nail in dermatological disease. Baran \& Dawber's Diseases of the Nails and Their Management, 257314.

Istiqomah, M. (2017). "Pengaruh Program Edukasi Dengan Metode Kelompok Terhadap Perilaku Perawatan Kaki Pada Penderita Diabetes Mellitus" Di Prolanis Binaan dr. Yunita. UNIVERSITAS MUHAMMADIYAH PONOROGO.

Keliat, B. A. (n.d.). dkk.(2011). Keperawatan Kesehatan Jiwa Komunitas.

Notoatmodjo, S. (2003). Pendidikan dan Perilaku Kesehatan, Jakarta: PT. Rineka Cipta.

Nursalam, D. (2014). Manajemen Keperawatan" Aplikasi dalam Praktik Keperawatan Profesional. Salemba Medika.

Nursalam, N., \& Efendi, F. (2008). Pendidikan Dalam Keperawatan Education in Nursing. Salemba Medika.

RI, K. (2020). Pedoman Kesiapsiagaan Menghadapi Corona virus Disease (COVID-19). Direkorat Jenderal Pencegahan Dan Pengendalian Penyakit.

Ronny, P. H. (2007). Ilmu penyakit kulit dan kelamin. Bagian Ilmu Penyakit Kulit Dan Kelamin FKUI. Jakarta.

Siregar, R. S. (2006). Saripati Penyakit Kulit Edisi 2. Jakarta: Penerbit Buku Kedokteran EGC.

Soemirat, J. (2011). Kesehatan Lingkungan. Yogyakarta. Gajah Mada University Press. 
Wulandari, T. S., Anisah, R. L., Fitriana, N. G., \& Purnamasari, I. (2020). Pengaruh Pendidikan Kesehatan Dengan Media Leaflet Untuk Meningkatkan Pengetahuan Dan Perilaku Dalam Upaya Menerapkan Protokol Kesehatan Pada Pedagang Di Car Free Day Temanggung. Jurnal Ilmiah Kesehatan, 10(2), 6-15.

Yasmadi. (2002). Modernisasi pesantren: kritikan Nurcholish Madjid terhadap pendidikan Islam tradisional. Ciputat Press. 